\title{
PHENYLTHIOCARBAMIDE NON-TASTING AMONG CONGENITAL ATHYROTIC CRETINS: FURTHER STUDIES IN AN ATTEMPT TO EXPLAIN THE INCREASED INCIDENCE *
}

\author{
By THOMAS H. SHEPARD, II $\dagger$
}

(From the Department of Pediatrics, University of Washington, Seattle, Wash.)

(Submitted for publication March 17, 1961 ; accepted May 18, 1961)

Phenylthiocarbamide (PTC) is a chemical compound which is bitter-tasting to approximately 70 per cent of white North Americans (1). The remaining 30 per cent has a discrete reduction in taste threshold. This non-tasting trait is inherited as a probable mendelian autosomal recessive (2-4). A common thionanide group structurally relates phenylthiocarbamide to thiourea, propylthiouracil and goitrin (see Figure 1). These four substances are also similar in their ability to interfere with the synthesis of thyroid hormone, an action which leads to thyroid hypertrophy.

PTC non-tasting has been shown to be more common in adult euthyroid patients with goiters $(5,6)$. In a preliminary report $(7)$, we have presented evidence that the incidence of non-tasting among congenital athyrotic cretins is significantly increased. The purposes of the present communication are to relate the taste threshold of these cretins to their intellectual development, birth weight, birth month, and race, to describe more fully the methods and clinical findings, and to demonstrate that the distribution by taste thresholds for goitrin, a naturally occurring goitrogen, is simliar to phenylthiocarbamide.

\section{METHODS}

The subjects and controls were tested by the author with 14 concentrations of phenylthiocarbamide, and the method used was that of Harris and Kalmus (8). Dilution 1 contains $1.3 \mathrm{mg}$ of PTC per $\mathrm{ml}$; each subse-

\footnotetext{
* Supported by Playtex Park Grant 74TR, National Institutes of Health Grant RG 6329CL and an Institutional Research Grant to the University of Washington by the American Cancer Society. Presented in part to the Society for Pediatric Research, Swampscott, Mass., May 4, 1960, and at the First International Congress of Endocrinology, Copenhagen, Denmark, July 19, 1960.

$\dagger$ Present address: Dept. of Anatomy, College of Medicine, J. Hillis Miller Health Center, Univ. of Florida, Gainesville, Fla.
}

quently numbered solution is one-half the strength of the preceding concentration. If a subject is able to taste only one of the concentrated solutions ( 1 through 4 ), he is designated a non-taster, whereas if his threshold is at dilution 5 through 14 , he is a taster. Plastic squirt bottles facilitated the procedure. By testing the parents first, the interest and cooperation of the child was often stimulated. For the adults, the taste threshold was determined by finding the weakest concentration at which they could differentiate 4 beakers of water from 4 beakers of

\section{Thiourea}

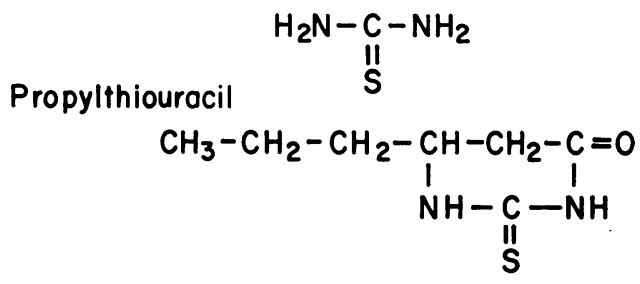

Phenylthiocarbamide P.T.C.<smiles>NC(=S)NC1CCCCC1</smiles>

Goitrin

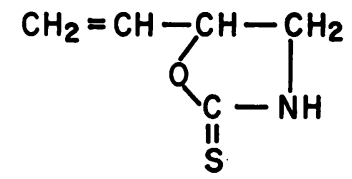

Fig. 1. Chemical formulas of the pertinent THIONAMIDES.

the test concentration. In children and infants, the concentration of solutions was increased until bitterness was detected by vocal response and grimace. This was repeated in most instances until the threshold was established by 3 responses at the same concentration. In Figure 2 the reproducibility of the test in children is illustrated. The average age in this group was 7.0 years.

Thresholds for taste of propylthiouracil, thiourea and goitrin ${ }^{1}$ were determined in adult volunteers by eliciting

1 The goitrin was in the $d, l$ form and was a gift from Dr. M. R. Altamura of the Pioneering Research Division, Quartermaster Research and Engineering Center, United States Army, Natick, Mass. 


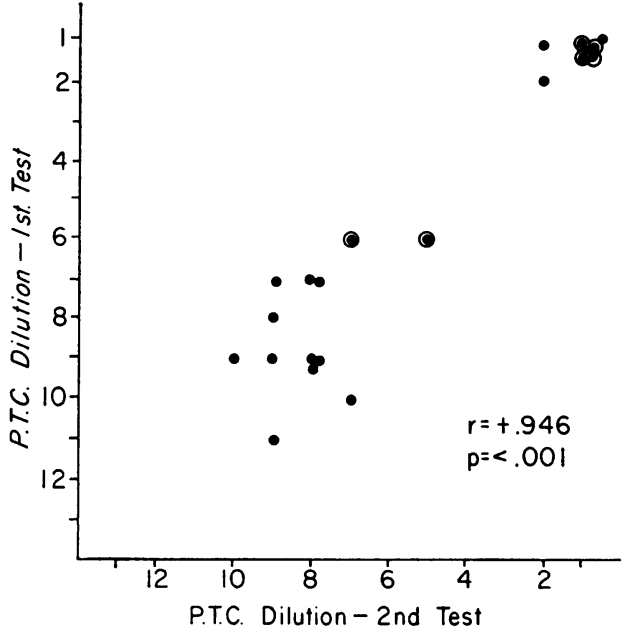

Fig. 2. Reproducibility of PTC thresholds in CHILDREN. The circled points indicate retested athyrotic cretins.

a response on 3 serial passages through the endpoint. The concentrations used are detailed in Figures 5, 6, and 7.

An analysis of the maternal dietary intake of antithyroid foods was undertaken by the use of questionnaires. The number of monthly servings for 20 substances was estimated by the mother for the usual diet and compared with the diet during pregnancy. Ten of these 20 foods
TABLE I

Foods in maternal diets investigated by questionnaire

\begin{tabular}{|c|c|c|}
\hline Food & $\begin{array}{l}\text { Antithyroid } \\
\text { effect } \\
(10,11,13)\end{array}$ & $\begin{array}{c}\text { Goitrin } \\
\text { isolated } \\
(9,11,12,14)\end{array}$ \\
\hline Rutabaga & + & + \\
\hline Turnip & + & + \\
\hline Cabbage & \pm & + \\
\hline Brussel sprouts & \pm & \\
\hline Broccoli & + & \\
\hline Peaches & + & \\
\hline Pears & + & \\
\hline Strawberries & + & \\
\hline Spinach & + & \\
\hline Peanuts & \pm & \\
\hline Carrots & + & \\
\hline Corn & - & \\
\hline Cauliflower & - & \\
\hline Pickles & & \\
\hline Peas & \pm & \\
\hline String beans & \pm & \\
\hline Soybeans & + & \\
\hline Milk & $\pm^{*}$ & $+^{*}$ \\
\hline Lettuce & \pm & \\
\hline Mustard & 二 & \\
\hline
\end{tabular}

* When goitrin-containing substances were administered to the cow.

are known to contain goitrin or to be thyroid-inhibiting in man (9-14) (Table I). Responses were obtained from 27 of the 30 mothers of cretins, and they were compared with 17 similar questionnaires completed by mothers of mentally retarded children.

TABLE II

Summary of clinical findings

\begin{tabular}{|c|c|c|c|c|c|c|c|c|c|c|c|c|c|c|}
\hline \multirow{3}{*}{ Case } & \multirow{3}{*}{ Sex } & \multirow{3}{*}{$\begin{array}{l}\begin{array}{l}\text { Birth } \\
\text { date }\end{array} \\
m o / y r\end{array}$} & \multirow{2}{*}{\multicolumn{2}{|c|}{$\begin{array}{c}\text { Age } \\
\text { tested }\end{array}$}} & \multirow{3}{*}{$\frac{\begin{array}{c}\text { Birth } \\
\text { wt }\end{array}}{g}$} & \multirow{3}{*}{$\begin{array}{l}\text { Typical } \\
\text { history }\end{array}$} & \multirow{3}{*}{$\begin{array}{l}\text { Treatment } \\
\text { before } \\
6 \mathrm{mo}\end{array}$} & \multirow{3}{*}{ IQ } & \multirow{3}{*}{$\frac{\text { PBI }}{\mu g / 100 m l}$} & \multirow{3}{*}{$\frac{\substack{24-\mathrm{Hr} \\
\mathrm{I}^{131}}}{\%}$} & \multicolumn{4}{|c|}{ PTC tkreshold } \\
\hline & & & & & & & & & & & Patient & Mother & Father & Siblings \\
\hline & & & yrs & mos & & & & & & & & & & \\
\hline 1 & F & $9 / 52$ & 6 & 10 & 2,380 & + & - & 50 & & 3 & ? & 5 & 8 & 11,9 \\
\hline 2 & $\mathrm{~F}$ & $8 / 58$ & 1 & & 2,380 & + & + & 109 & 3.2 & 0.3 & 6 & 7 & & \\
\hline 3 & $\mathbf{M}$ & $7 / 55$ & 4 & & 2,870 & + & + & 78 & 3.2 & 3.3 & 1 & 3 & 10 & \\
\hline 4 & F & $6 / 55$ & 4 & 1 & 3,150 & + & - & 64 & 2.7 & 0 & ? & 11 & 9 & 8 \\
\hline 5 & $\mathrm{~F}$ & $5 / 55$ & 4 & 2 & 3,600 & + & + & normal* & & & i & 1 & 3 & \\
\hline 6 & $\mathrm{~F}$ & $10 / 57$ & 1 & 9 & 5,100 & + & + & 52 & 3.5 & 1.6 & 1 & 1 & 1 & \\
\hline 7 & $\mathrm{~F}$ & $1 / 54$ & 5 & 6 & 3,820 & + & + & 85 & & 0 & 6 & 6 & & 7 \\
\hline 8 & $\mathbf{M}$ & $1 / 56$ & 3 & 6 & 1,920 & + & - & 38 & 2.8 & 6.1 & $?$ & 4 & 10 & 3 \\
\hline 9 & $\mathrm{~F}$ & $9 / 55$ & 3 & 10 & 3,490 & + & + & 100 & 3.1 & & 1 & 2 & 8 & \\
\hline 10 & $\mathrm{~F}$ & $9 / 58$ & & 11 & 3,150 & + & + & normal* & 2.3 & & 1 & 1 & 7 & \\
\hline 11 & $\mathrm{~F}$ & $9 / 46$ & 12 & & 3,610 & + & + & 74 & & & 1 & 1 & 6 & 1,2 \\
\hline 12 & $\mathrm{~F}$ & $6 / 57$ & 2 & 2 & 4,080 & + & + & $50-60$ & 1.0 & 5 & 6 & 8 & 9 & \\
\hline 13 & $\mathrm{~F}$ & $2 / 47$ & 12 & 6 & 3,080 & + & + & 117 & & & 1 & 1 & & $3,2,4,1,1,8$ \\
\hline 14 & $\mathrm{~F}$ & $10 / 57$ & 1 & 10 & 4,600 & + & + & 124 & & & 8 & 11 & 5 & \\
\hline 15 & $\mathbf{M}$ & $5 / 56$ & 3 & 3 & 3,600 & + & + & 95 & 1.6 & & 6 & 10 & 7 & 10 \\
\hline 16 & $\mathbf{M}$ & $5 / 56$ & 3 & 3 & 4,200 & + & + & 113 & 2.2 & & 7 & 10 & 7 & 10,4 \\
\hline 17 & $\mathbf{M}$ & $1 / 58$ & 1 & 8 & 3,100 & + & + & low normal* & 1.0 & & 2 & 1 & 7 & \\
\hline 18 & $\mathrm{~F}$ & $9 / 55$ & 4 & & 3,610 & + & + & 82 & 1.2 & 1 & $\overline{1}$ & 4 & 4 & 1 \\
\hline 19 & M & $1 / 56$ & 3 & 8 & 2,950 & + & + & 60 & 1.0 & 10 & 1 & 7 & 1 & \\
\hline 20 & $\mathbf{F}$ & $11 / 53$ & 5 & 10 & 3,610 & + & - & 38 & 1.0 & & $?$ & 8 & 1 & \\
\hline 21 & $\mathbf{M}$ & $1 / 58$ & 1 & 8 & 3,940 & + & + & low normal* & 0.6 & 8 & 6 & 9 & 10 & \\
\hline 22 & $\mathrm{~F}$ & $5 / 55$ & 4 & 5 & 3,200 & + & - & 106 & 1.0 & 8 & 1 & 1 & 1 & 1,1 \\
\hline 23 & $\mathbf{F}$ & $1 / 47$ & 12 & 8 & 2,950 & + & + & 101 & & & 2 & 1 & 1 & 2 \\
\hline 24 & $\mathbf{F}$ & $3 / 53$ & 6 & 6 & 3,820 & + & + & 85 & 0.8 & low & 8 & 9 & 7 & \\
\hline 25 & $\mathbf{M}$ & $2 / 56$ & 3 & 6 & 4,170 & + & + & 92 & 2.0 & 0 & 10 & & & \\
\hline 26 & $\mathrm{~F}$ & $8 / 47$ & 12 & 1 & 3,220 & + & - & 60 & & low & 1 & 1 & 1 & 1 \\
\hline 27 & $\mathbf{M}$ & $12 / 51$ & 7 & 9 & 4,000 & + & + & 105 & & & 1 & 8 & 1 & 2,4 \\
\hline 28 & $\mathrm{~F}$ & $12 / 50$ & 8 & 9 & $\mathbf{3 , 4 4 0}$ & + & + & 48 & 3.4 & & i & 1 & 2 & 5 \\
\hline 29 & $\mathrm{~F}$ & $8 / 49$ & 10 & 1 & 3,900 & + & - & 83 & & low & 1 & 9 & 1 & 12 \\
\hline 30 & $\mathbf{M}$ & $9 / 44$ & 15 & & 4,000 & + & - & 60 & & low & 1 & 7 & 8 & 1 \\
\hline 31 & $\mathbf{M}$ & $6 / 47$ & 12 & 3 & 3,060 & + & - & 85 & & low & 1 & 1 & 1 & \\
\hline
\end{tabular}

* Not tested by formal psychometric examination. 
The psychometric evaluations of intelligence were performed by different examiners in 27 of the patients. The remaining 4 children were not formally tested.

Correlation coefficients and $\chi^{2}$ tests were calculated with the formulas of Edwards (15).

Clinical material. The 31 congenital athyrotic cretins and their families were from the clinics of university hospitals in several sections of North America. ${ }^{2}$ The diagnosis was based on typical signs and symptoms of cretinism which appeared during the first 4 months of life. All of the patients had a history of enlarged tongue, myxedema, umbilical hernia, growth arrest, and dramatic response to thyroid therapy. If the history suggested an acquired type of cretinism (i.e., cutting teeth or normal growth and development during the first year), the patient was classified before taste testing as having acquired hypothyroidism. In 25 of the 31 congenital athyrotic cretins studied, either a serum protein-bound iodine or an $\mathrm{I}^{131}$-thyroidal accumulation, or both, supported the diagnosis (Table II). There were 20 females and 11 males; Subjects 24 and 25 were brother and sister. Only one child was living in a school for the mentally handicapped.

The control group consisted of adults working in the University of Washington Medical School and children attending out-patient clinics of the University Hospital, and the Children's Orthopedic Hospital of Seattle. None of the controls had thyroid disease.

\section{RESULTS}

Athyrotic cretins. The results of PTC testing are shown in Table II and Figure 3 . In four of the cretins, the threshold could not be accurately determined. Of the remaining 27, 18 were nontasters and 9 were tasters; in the control group, which consisted of 42 adults and 62 children, there were 29 non-tasters (Figure 3). The incidence of non-tasting in the cretinous group was significantly elevated $\left[\chi^{2}=22.0\right.$, degrees of freedom (D.F.) $=1, \mathrm{p}<0.001]$.

In a group of 13 children with acquired hypothyroidism, 4 were PTC non-tasters. Three of the 13 children had a goitrous form of cretinism and were tasters.

The intelligence quotients of the tasters are compared with the non-tasters in Figure 4. There

2 Subjects 1-11 were from the Pediatric Endocrine Clinics of the University Hospital and of the Children's Orthopedic Hospital, Seattle, Wash.; 12-16 were made available by Dr. Geoffrey Robinson, Dept. of Pediatrics, Univ. of British Columbia, Vancouver, B. C. ; 17-21 were from the clinic of Dr. John Crigler, Dept. of Pediatrics, Harvard Medical School, Boston, Mass.; 22-31 were from the clinic of Dr. Lawson Wilkins, Dept. of Pediatrics, Johns Hopkins Hospital, Baltimore, Md.
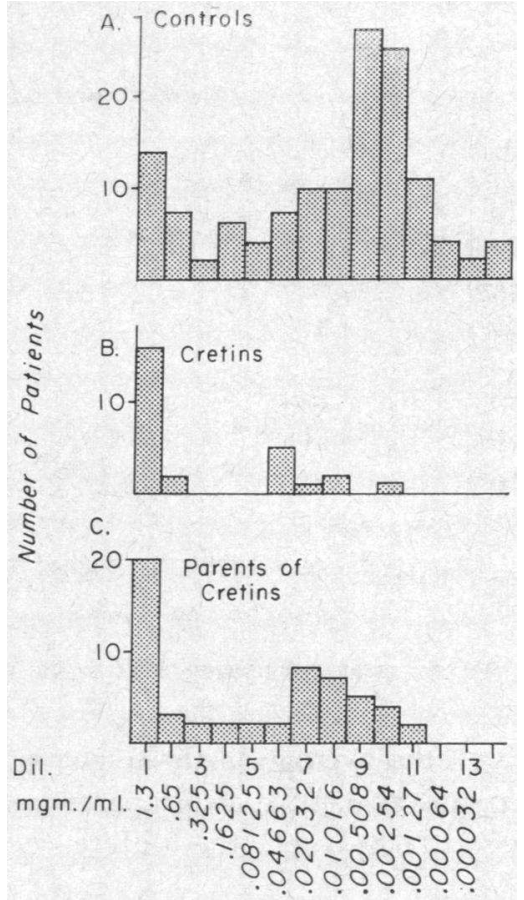

Fig. 3. Threshold dilutions of PTC FOR THE MEMBERS OF THREE GROUPS. Dilutions 1 to 4 designate a nontaster; dilutions 5 to 14 designate a taster.

was no statistically significant correlation between the IQ rating and PTC-tasting threshold, but 7 of the 15 non-tasters had a ratio below 80 whereas only one of the 8 tasters was below 80 . When the 9 patients who were treated after 6 months of age were excluded from the sample, there was no increase in significance of correlation.

No relationship between taste status and the year or month of birth was noted.

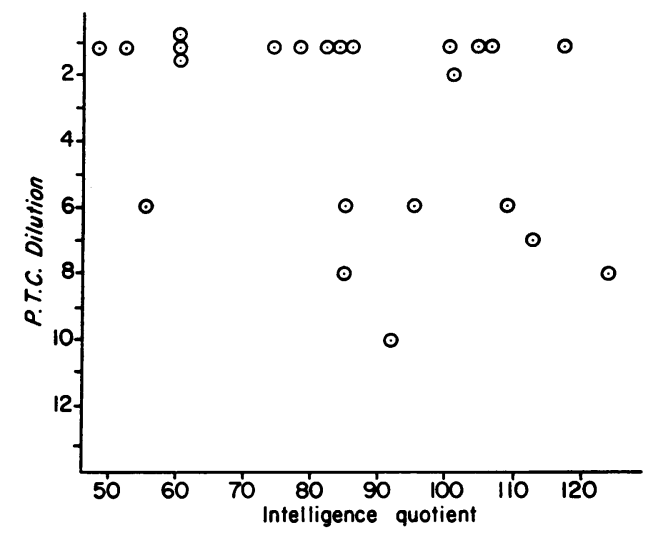

Fig. 4. INTELLIGENCE QUOTIENTS OF THE FORMALLY TESTED CRETINS ARE COMPARED WITH THEIR PTC THRESHOLD. 


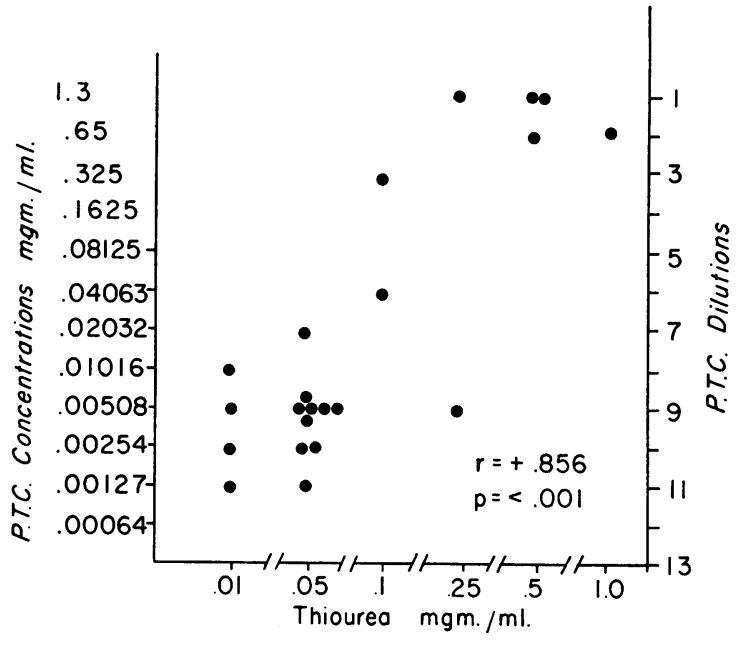

Fig. 5. TASte thresholds For PTC ANd thiourea.

Although the average birth weight in the nontaster group was $3,465 \mathrm{~g}$ as compared with that of the tasters $(3,845 \mathrm{~g})$, the difference was not significant.

Families of the cretins. The incidence of PTC non-tasting among the parents was significantly elevated $\left(x^{2}=21.6\right.$, D.F. $\left.=1, p<0.001\right)$. Of 30 mothers who were tested, 15 were non-tasters and 12 of the 27 tested fathers were non-tasters; 18 of the 29 unaffected siblings were non-tasters.

All of the parents were Caucasian but one, who was Negro. One parent was of Mediterranean ancestry; the remainder were descended from persons who had migrated from northern European countries.

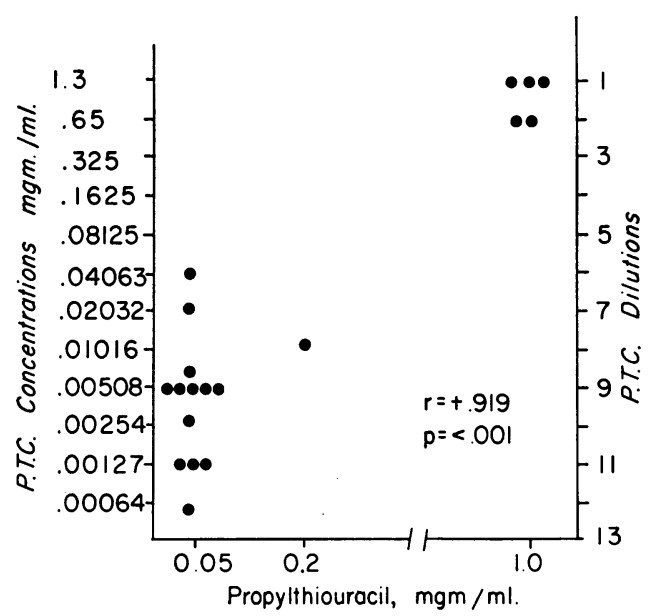

Fig. 6. CoMparison of tASTE THRESHOLdS For PTC AND PROPYLTHIOURACIL.

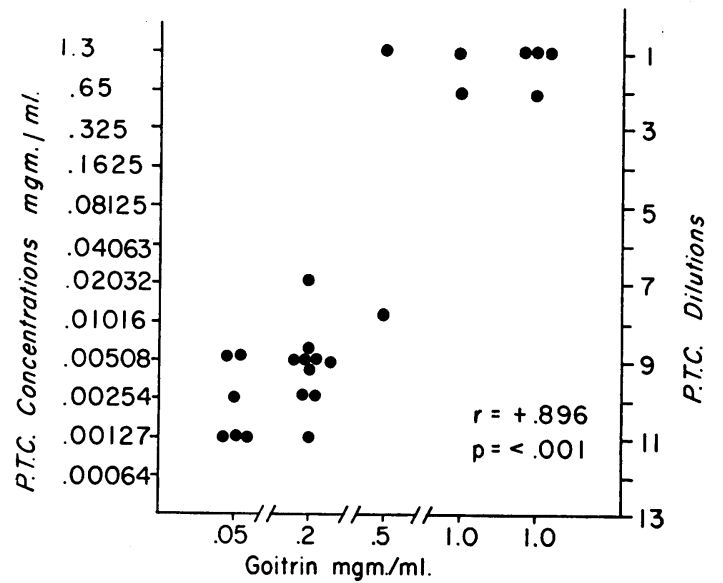

Fig. 7. Comparison of tASTE Thresholds FOR PTC AND $d, l$ GOITRIN.

Of the total number of 99 pregnancies reported by the mothers, 12 (12.1 per cent) ended in abortion.

Thyroid disease in the parents was assessed by history and, where possible, augmented by examination of the subject's neck; in four, clear evidence of thyroid hypertrophy was evident. One of these parents had been thyroidectomized for hyperthyroidism; the others were euthyroid.

An analysis of the questionnaires covering maternal dietary intake of antithyroid foods revealed that the mothers of cretins showed no differences from the control group of mothers of mentally retarded noncretinous children.

Taste thresholds for other thionamides. The taste thresholds for thiourea, propylthiouracil and goitrin were compared with the PTC thresholds in the same volunteers. In each case, a significant positive correlation was obtained. The correlation coefficients and concentrations used are detailed in Figures 5, 6 and 7.

\section{DISCUSSION}

Although attempts to define PTC non-tasting biochemically or physiologically $(16,17)$ have been made, no definition has been firmly established. The perception of PTC is localized to the group of taste buds on the posterior aspect of the tongue. Harris and Kalmus (18) have previously shown that other thionamides such as thiourea and propylthiouracil exhibit the same taste difference as PTC. Our findings support their observations and extend this group of thionamides 
to include goitrin (l-5-vinyl-2-thio-oxazolidone) which is a naturally occurring antithyroid substance (9-14).

A significantly increased incilence of PTC nontasting has been demonstrated in this group of athyrotic cretins. Because the non-tasting trait is a probable mendelian recessive (2-4), the finding of an increased incidence of non-tasting among the parents and among the siblings helps to exclude the possibility that the testing is inaccurate due to the lowered mentality among cretins. Fraser (19) has tested with PTC 17 of 28 children with a presumptive diagnosis of athyrotic cretinism; 15 were non-tasters.

If cretinism is more common among non-tasters, one would expect fewer cases of congenital hypothyroidism in populations with a lowered incidence of the trait. Non-tasting occurs in only 2 to 10 per cent of the Negro race as compared with an incidence of 30 per cent in non-colored North Americans (20). Publications by Scott and Jenkins (21) and by Childs and Gardner (22) have emphasized that cretinism is uncommon in the Negro race. Scott (23) reports that only two cretinous patients have been admitted to the Pediatric Service of Freedman's Hospital during a 20-year period. A high proportion of patients in this hospital is colored. Childs and Gardner (22) observed only two Negroes in a group of 90 cretins from the Johns Hopkins Hospital. The author has been unsuccessful in learning the incidence of cretinism in other racial populations which have a high percentage of non-tasters, and would appreciate receiving information on this point.

A possible relationship between PTC nontasting and other features of cretinism was noted only in the case of intelligence quotients, but here the increased intelligence of the tasters over the non-tasters is only suggestive. It was found that the five patients examined in British Columbia (Cases 12-16) were more intelligent and had normal incidence of PTC tasting. A separate pediatrician referred each of these patients, and, therefore, their selection differed from that in the other groups where the sample included a large majority of the cretins attending a particular clinic. It might be natural for an individual pediatrician to refer his most successfully treated patient and thereby possibly select out a different group. On the other hand, the histories of these patients did not differ from the other cretins. It may be pertinent at this point to mention that children with a later developing form of cretinism (goitrous or non-goitrous) had a normal incidence of non-tasting and generally normal mental development.

Hypotheses based on findings. What is the connection between the PTC non-tasting genotype and athyrotic cretinism? Because of the chemical similarity between PTC and other antithyroid drugs and because of the increased susceptibility of non-tasting adults to thyroid disease $(5,6)$, it is tempting to speculate that the fetus with non-tasting genotype is more susceptible to thyroid maldevelopment. Since the non-tasting state occurs in the normal siblings of the cretins, the PTC non-tasting by itself does not seem to account for athyrotic cretinism but may lead to circumstances which affect organogenesis of the thyroid. There is no evidence from our questioning that the mothers of the cretins have a higher intake of goitrin-containing foods. It should be pointed out that, although some vegetables contain significant amounts of goitrin (9-13), Greer and Deeney have shown that it exists as its glycoside, progoitrin $(24,25)$. Progoitrin which elicits antithyroid activity (25) is only slightly better and as a result might be unknowingly ingested in large amounts.

A mechanism that might lead to thyroid maldevelopment is an inability of the PTC non-taster to normally detoxify thionamide goitrins such as goitrin. Maloof and Spector (26) have shown that the particulate fraction of sheep thyroid cells has a desulfurating mechanism for the thionamide, thiourea. Similar preparations from sheep liver and kidney did not desulfurate. We have shown that a particulate fraction from human thyroid desulfurates $S^{35}$-thiourea (27). If the PTC nontaster were unable to desulfurate thionamides, his thyroid metbolism might be differentially affected by these substances.

Although thionamides can cross the mammalian placenta and exert an inhibiting effect on fetal thyroid, there is no experimental evidence in animals $(28-37)$ or in man $(37,38)$ that they can prevent thyroid embryogenesis. 
SUM M ARY

The incidence of non-tasting for phenylthiocarbamide (PTC), a mendelian recessive trait, is significantly increased among congenital athyrotic cretins and their families. Speculations to explain this finding are discussed. There is no evidence that the maternal intake of goitrogenic foods was abnormal.

An insensitivity to taste perception for goitrin, thiourea, and propylthiouracil was demonstrated in volunteers who were also non-tasters for PTC.

\section{ACKNOWLEDGMENTS}

The kind cooperation of Drs. John Crigler, Lawson Wilkins, and Geoffrey Robinson in making patients available for study is much appreciated. The author wishes to thank Drs. William Cleveland, Raphael David, Michael Rigg and Barbara Rubin for help in studying the families; and Drs. John Money, Riva Potashin and Robert Burns for performing the psychological testing on many of the patients. Dr. Stanley Gartler's help with the genetic aspects and Miss Nan Bernstein's help with the nutritional analysis is gratefully acknowledged. A large number of volunteers, including members of the families studied, cheerfully cooperated in the studies.

\section{REFERENCES}

1. Fox, A. L. The relationship between chemical constitution and taste. Proc. nat. Acad. Sci. (Wash.) $1932,18,115$.

2. Blakeslee, A. F. Genetics of sensory thresholds: Taste for phenylthiocarbamide. Proc. nat. Acad. Sci. (Wash.) 1932, 18, 120.

3. Snyder, L. H. Studies in human inheritance: IX. The inheritance of taste deficiency in man. Ohio J. Sci. 1932, 32, 436.

4. Das, S. R. A contribution to the heredity of PTC taste character based on a study of 845 sib pairs. Ann. Eugen. (Lond.) 1956, 20, 334.

5. Harris, H., Kalmus, H., and Trotter, W. R. Taste sensitivity to phenylthiourea in goitre and diabetes; preliminary communication. Lancet 1949, 2, 1038.

6. Kitchin, F. D., Howel-Evans, W., Clarke, C. A., McConnell, R. B., and Sheppard, P. M. P. T. C. taste response and thyroid disease. Brit. med. J. 1959, 1, 1069.

7. Shepard, T. H., II, and Gartler, S. M. Increased incidence of non-tasters of phenylthiocarbamide among congenital athyreotic cretins. Science 1960, $131,929$.

8. Harris, H., and Kalmus, $H$. The measurement of taste sensitivity to phenylthiourea (PTC). Ann. Eugen. (Lond.) 1950, 15, 24.

9. Astwood, E. B., Greer, M. A., and Ettlinger, M. G. L-5-vinyl-2-thiooxazolidone, an antithyroid com- pound from yellow turnip and from Brassica secds. J. biol. Chem. 1949, 181, 121.

10. (ireer, M. A., and Astwood, E. B. Antithyroid effect of certain foods in man as determined with radioactive iodine. Endocrinology 1948, 43, 105.

11. Greer, M. A. Goitrogenic substances in food. Amer. J. clin. Nutr. 1957, 5, 440.

12. Kreula, M., and Kiesvaara, M. Determination of L-5-vinyl-2-thiooxazolidone from plant material and milk. Acta chem. scand. 1959, 13, 1375.

13. Clements, F. W. Naturally occurring goitrogens. Brit. med. Bull. 1960, 16, 133.

14. Altamura, M. R., Long, L., Jr., and Hasselstrom, T. Goitrin from fresh cabbage. J. biol. Chem. 1959, 234, 1847.

15. Edwards, A. L. Statistical Methods for the Behavioral Sciences. New York, Rinehart, 1955, pp. 147, 384.

16. Cohen, J., and Ogdon, D. P. Taste blindness to phenyl-thio-carbamide as a function of saliva. Science 1949, 110, 532.

17. Griffin, F., and Fischer, R. Differential reactivity of saliva from "tasters" and "non-tasters" of 6-npropylthiouracil. Nature (Lond.) 1960, 187, 417.

18. Harris, H., and Kalmus, $H$. Chemical specificity in genetical differences of taste sensitivity. Ann. Eugen. (Lond.) 1950, 15, 32.

19. Fraser, G. R. Cretinism and taste sensitivity to phenylthiocarbamide. Lancet 1961, 1, 964.

20. Allison, A. C., and Blumberg, B. S. Ability to taste phenylthiocarbamide among Alaskan eskimos and other populations. Hum. Biol. 1959, 31, 352.

21. Scott, R. B., and Jenkins, M. E. Hypothyroidism in Negro children. J. Pediat. 1954, 44, 307.

22. Childs, B., and Gardner, L. I. Etiologic factors in sporadic cretinism: An analysis of 90 cases. Ann. hum. Genet. 1954, 19, 90.

23. Scott, R. B. Personal communication.

24. Greer, M. A. Isolation from rutabaga seed of progoitrin, the precursor of the naturally occurring antithyroid compound, goitrin (L-5-vinyl-2-oxazolidinethione). J. Amer. chem. Soc. 1956, 78, 1260.

25. Greer, M. A., and Deeney, J. M. Antithyroid activity elicited by the ingestion of pure progoitrin, a naturally occurring thioglycoside of the turnip family. J. clin. Invest. 1959, 38, 1465.

26. Maloof, F., and Spector, L. The desulfuration of thiourea by thyroid cytoplasmic particulate fractions. J. biol. Chem. 1959, 234, 949.

27. Shepard, T. H., and Gartler, S. M. Unpublished data.

28. Jost, A. Le problème des interrelations thyréohypophysaires chez la foetus et l'action du propylthiouracile sur la thyroïde foetale. Revue suisse Zool. 1957, 64, 821.

29. Knobil, E., and Josimovich, J. B. Placental transfer of thyrotropic hormone, thyroxine, triiodothyronine, and insulin in the rat. Ann. N. Y. Acad. Sci. 1959, 75, 895. 
30. Hoskins, L. C., Van Arsdel, P. P., Jr., and Williams, R. H. Placental transmission and mammary gland secretion of thyroxin in the rat. Amer. J. Physiol. 1958, 193, 509.

31. Sobel, E. H., Hamburgh, M., and Koblin, R. Development of fetal thyroid in rats: Evidence for transfer of thyroxine (abstract). Amer. J. Dis. Child. 1960, 100, 709.

32. Maillard, M. Action du propylthiouracile sur fixation de $\mathrm{I}^{131}$ par la thyroide foetale du rat. C. $\mathrm{R}$. Soc. Biol. (Paris) 1959, 153, 1903.

33. Jost, A. Action du propylthiouracile sur la thyroïde $\mathrm{du}$ foetus de lapin intact, décapité ou injecté de thyroxine. C. R. Soc. Biol. (Paris) 1959, 153, 1900.
34. Clements, F. W. A goitrogenic factor in milk. Med. J. Aust. 1957, 44, 645.

35. Romanoff, A. L. The Avian Embryo; Structural and Functional Development. New York, Macmillan, 1960, pp. 874-876.

36. Sinha, M. D., Ringer, R. K., Coleman, T. H., and Zindel, H. C. The effect of injected thiouracil on body weight and hatchability of the chick embryo. Poultry Sci. 1959, 38, 1405.

37. Krementz, E. T., Hooper, R. G., and Kempson, R. L. The effect on the rabbit fetus of the maternal administration of propylthiouracil. Surgery 1957, 41, 619.

38. Man, E. B., Shaver, B. A., Jr., and Cooke, R. E. Studies of children born to women with thyroid disease. Amer. J. Obstet. Gynec. 1958, 75, 728. 